\title{
Mucor racemosus as a biosorbent of metal ions from polluted water in Northern Delta of Egypt
}

\author{
El-Morsy EM, Nour El-Dein MM and El-Didamoney SMM
}

\author{
Department of Botany, Faculty of Science, Damietta University, New Damietta, Egypt.
}

El-Morsy EM, Nour El-Dein MM, El-Didamoney SMM 2013 - Mucor racemosus as a biosorbent of metal ions from polluted water in Northern Delta of Egypt. Mycosphere 4(6), 1118-1131, Doi 10.5943/mycosphere/4/6/9

\begin{abstract}
Twenty samples of polluted water were collected from Damietta's canals and drainages located near the industrial area of New Damietta. Initial concentrations of heavy metals including (zinc, copper and lead) in the polluted water were determined. Fourty-five fungal species were isolated. Mucor racemosus, Aspergillus flavus, A. niger, A. fumigatus, Trichoderma koningi and Rhizopus oryzae were isolated frequently. On the basis of its frequency, Mucor racemosus was chosen for biosorption studies.

Free and immobilized biomass of Mucor racemosus sequestered ions in this decreasing sequence $\mathrm{Cu}>\mathrm{Zn}>\mathrm{Pb}$. The effects of biomass concentration, $\mathrm{pH}$ and time of contact were investigated. The level of ion uptake rose with increasing biomass till $200 \mathrm{mg}$ and then decreased with increasing biomass. The maximum uptake for $\mathrm{Cu}(60.13 \mathrm{mg} / \mathrm{g}), \mathrm{Zn}(57.67 \mathrm{mg} / \mathrm{g})$ and $\mathrm{Pb}$ $(21.97 \mathrm{mg} / \mathrm{g}$ ) respectively occurred at $200 \mathrm{mg} / \mathrm{l}$ biomass. The uptake rose with increasing $\mathrm{pH}$ up to 5 in the case of $\mathrm{Zn}$ and $\mathrm{Cu}$ and 4 in the case of $\mathrm{Pb}$. Maximum uptake for all metals was achieved after 15 minutes. Ion uptake followed the Langmuir adsorption model, permitting the calculation of maximum uptake and affinity coefficients. Treatment of Mucor racemosus biomass with $0.1 \mathrm{M}$ $\mathrm{NaOH}$ at $120^{\circ} \mathrm{C}$ for $6 \mathrm{~h}$ improved biosorbent capacity, as did immobilization with alginate. Immobilized biomass could be regenerated readily with treatment with dilute $\mathrm{HCl}$. The biomassalginate complex efficiently removed $\mathrm{Zn}, \mathrm{Cu}$ and $\mathrm{Pb}$ from polluted water samples. Therefore, Mucor racemosus could be employed either in free or immobilized form as a biosorbent of metal ions in waste water.
\end{abstract}

Key words - alginate - alkali treatment - biosorption - copper - free and immobilized biomass lead - zinc.

\section{Introduction}

The increasing trends towards artificial high life standards are compelling the people towards misuse of resources resulting in environmental degradation at massive scale. Incidentally, increased industrialization has affected the environment through disposal of waste water containing toxic contaminants in the form of metals. This situation is getting more alarming in the last two decades where industrial units are established without environmental impacts assessment and planning. Therefore discharge of heavy metals, their accumulation and contamination has become an environmental, health, economic and planning issue. 
Biological methods of metals removal from aqueous solution, known as biosorption have been recommended as cheaper and more effective technique in bioremoval of heavy metals (Apel \&Torma 1993, Artola et al. 1997). Biosorption of metals is a property of certain types of microbial biomass that can result in the concentration of metallic elements from relatively diluted solutions (Volesky \& Philips 1995). Biosorption has received substantial attention as a potential method for decontamination and recovery of heavy metals from the environment (Lewis \& Kiff 1988, Venkateswerlu \& Stotzky 1989, Luef et al. 1991). Fungal biomass and seaweed biomass have been found to be excellent biosorbents for sequestering heavy metals (Lewis \& Kiff 1988, Holan \& Volesky 1994, Volesky \& Holan 1995). Fungal biomass has been used to sequester copper, lead, zinc, nickel, cadmium, gold, silver and various actinide elements, such as thorium, uranium and plutonium (Tsezos \& Volesky 1981, Gadd \& White 1989, Luef et al. 1991, Kapoor \&Viraraghavan $1998 \mathrm{a} \& \mathrm{~b})$.

Fungi are known to have good metal uptake systems (Gadd 1986) with metabolismindependent biosorption being the most efficient. The specific mechanism of uptake differs quantitatively and qualitatively according to the species, the origin of the biomass and its processing (Tobin et al. 1984). The hyphal wall was found to be a primary site of metal ion accumulation. This is attributed to several chemical groups (the acetamido group of chitin, amino and phosphate groups in nucleic acids, amino acids, amido, sulfhydryl and carboxyl groups in proteins and hydroxyls in polysaccharides) that might attract and sequester metal ions (Holan \& Volesky 1995).

Biomass of fungi such as Absidia, Cunninghamella, Mucor and Rhizopus, exhibit excellent metal-ion uptake (Venkateswerlu \& Stotzky 1989, Luef et al. 1991, Fourest \& Roux 1992, Mueler et al. 1992). This could be due to the high chitin and chitosan content of the cell walls of these fungi (Tsezos \& Volesky 1981). To date, research in the area of biosorption suggests it to be an ideal alternative for decontamination of metal containing effluents (Yazdani et al. 2010, Nur Liyana et al. 2011, Nitin et al. 2012, Siddiquee et al. 2013). Generally speaking the biosorption takes place by both living and non-living microbial biomass, but there are differences in the efficiency and mechanisms involved (Park et al. 2005). The efficiency by which dead cells act as sorbent of metal ion may be greater than that of living cells and confirm its wider acceptability. This is due to the argument that dead cells do not have toxicity limitations, no requirement of growth and nutrient media, storage property for extended time period and easy desorption of adsorbed metal ions (Awofolu et al. 2006).

Various physical (heat treatment, autoclaving, freeze drying and boiling) and chemical (acids, alkali and organic chemicals) pretreatment protocols have been developed to convert the viable cells into nonviable (dead) (Loukidou et al. 2003). According to many workers, the chemical pretreatment protocols owing to change in cell wall chemistry of the biosorbent (Kapoor et al. 1999). Yan \& Viraraghavan 2000 has reported that alkaline (caustic) treatment could enhance metal binding by biomass.

The alkaline treatments, including sodium hydroxide, potassium hydroxide, alkaline detergents or other alkaline reagents ruptures the cell walls of microbes and exposes additional functional groups for metal ion binding. The residual alkalinity may result in the hydrolysis of certain metals, thus enhancing the biosorption capacity of biomass (Brierley 1990). According to Huang (1996) acid-washing process have better results over other treatments as this treatment may dissolve polysaccharide components in the outer cell wall layer of the biosorbent, thus producing additional binding sites. It is obvious that many different and challenging contributions have been made on the path to develop biosorption by the biosorbent.

Therefore the aim of this study was to isolate fungi from polluted water to find a new biosorbent agent. The ability of free and immobilized biomass of this biosorbents to sequester zinc $(\mathrm{Zn})$, copper $(\mathrm{Cu})$ and lead $(\mathrm{Pb})$ was investigated. 


\section{Materials and Methods}

\section{Sampling procedures and isolation methods}

Twenty water samples were collected in May 2010 from polluted water of Damietta's drainages and canals located near the industrial area of New Damietta in clean, sterilized 1 L screwcap glass bottles. To each sample, $372 \mathrm{mg} / \mathrm{l}$ of EDTA (ethylene diamine-tetraacetic acid disodium salt) was added as a chelating agent to reduce toxicity in samples laden with heavy metals. Other twenty samples were also collected in clean, sterilized screw-cap glass bottles for the determination of heavy metals concentration in the polluted water samples.

Examination of samples began immediately after return to the laboratory. For isolation of fungi a millipore filter paper ( $0.45 \mathrm{~m} \mu$ pore size) technique was used to concentrate fungal propagules from the polluted water. The fungal propagules were resuspended in sterilized bottles containing 50 or $100 \mathrm{ml}$ of sterilized water, and $1 \mathrm{ml}$ from each dilution was transferred to a clean sterilized petri-dish (three replicates) contained streptopenicid $(0.35 \mathrm{~g} / \mathrm{ml})$, rose bengal $(0.035 \mathrm{gm} / \mathrm{ml})$ glucose $(10 \mathrm{gm} / \mathrm{l})$, peptone $(5 \mathrm{gm} / \mathrm{l})$ and agar $(15 \mathrm{gm} / \mathrm{l})($ Cooke 1963$)$. The plates were incubated at $28^{\circ} \mathrm{C}$ for $4-7$ days. The relative frequency of occurrence was calculated as the number of species isolated from each sample divided by the total number of samples. The isolated species were classified as very frequent $(>20 \%)$, frequent $(10-20 \%)$, or infrequent $(<10 \%)$ as adapted from (Tan and Leong 1989). Sporulating isolates were identified using specific media that were used for identifying sporulating isolates. Non-sporulating strains were grouped as mycelia sterilia according to similarities in colony morphology (Taylor et al. 1999).

\section{Metal biosorption by free fungal biomass}

Mucor racemosus was selected based on its frequent occurrence in sampling. The fungus was subcultured on Potato Dextrose broth at $28^{\circ} \mathrm{C}$ for 7 days on a rotatory shaker at $180 \mathrm{rpm}$. Fungal pellets were washed twice in sterile double distilled water, drained and dried at $60^{\circ} \mathrm{C}$ to constant weight and ground with a mortar and pestle before determination of metal biosorption (ElMorsy 2004).

\section{Effect of initial metal concentration}

To evaluate the effect of initial metal ion concentration $\left(\mathrm{c}_{\mathrm{i}}\right)$ on adsorption behaviour of $\mathrm{Zn}$, $\mathrm{Cu}$ and $\mathrm{Pb}$ by dried mycelial biomass, aliquots of 10, 50, 70, 100, 150, 200,300, 400 and $600 \mathrm{ppm}$ concentration of zinc sulfate, copper sulfate and lead acetate solutions were added to $250 \mathrm{ml}$ Erlenmeyer flasks with a fixed biomass of $200 \mathrm{mg} / \mathrm{l}$. The $\mathrm{pH}$ was adjusted to 4 with $0.1 \mathrm{~N} \mathrm{HCl}$ and $0.1 \mathrm{~N} \mathrm{NaOH}$. The samples were mixed well by shaking. For sorption isotherm experiments, flasks were agitated on a rotatory shaker $(180 \mathrm{rpm})$ at room temperature until no additional metal was removed (3-5 h). The samples were filtered through $0.45 \mathrm{~m} \mu$ millipore filters. Triplicate samples were analyzed by A Perkin-2380 atomic absorption spectrophotometry. Samples also were taken from experimental controls, which contain no biomass (El-Morsy 2004).

\section{Effect of biomass concentration}

To evaluate the effect of biomass concentration on the adsorption behaviour of $\mathrm{Zn}, \mathrm{Cu}$ and $\mathrm{Pb}$. Biomass concentrations of 100, 200 and $300 \mathrm{mg} / \mathrm{l}$ were added to $250 \mathrm{ml}$ Erlenmeyer flasks separately. Aliquots $(50 \mathrm{ml})$ of heavy metal solution $(100,200$ and $300 \mathrm{mg} / \mathrm{l})$ were added to each flask, and the flasks were left 15 minutes on a rotatory shaker at $180 \mathrm{rpm}$ at room temperature before being analyzed as above (El-Morsy 2004).

\section{Effect of pH}

A Sorption of metal ions by dried mycelial biomass was studied at $\mathrm{pH}$ values of 2, 2.5, 3, $3.5,4,4.5,5,5.5,6$ and 6.5. The samples were shaken at $180 \mathrm{rpm}$ using a rotatory shaker at room 
temperature. A fixed biomass of $200 \mathrm{mg} / \mathrm{l}$ was added to $50 \mathrm{ml}$ of heavy metal solution containing $\mathrm{Zn}, \mathrm{Cu}$ and $\mathrm{Pb}$ at an initial concentration of $200 \mathrm{mg} / \mathrm{l}$ for 15 minutes. To avoid shifts in $\mathrm{pH}$ due to biomass addition, the $\mathrm{pH}$ was adjusted with $0.1 \mathrm{~N} \mathrm{HCl}$ and $0.1 \mathrm{~N} \mathrm{NaOH}$ after the solution had been in contact with the adsorbent. In the case of $\mathrm{Pb}, \mathrm{pH}$ was adjusted with $0.1 \mathrm{~N} \mathrm{HNO}_{3}$ or $0.1 \mathrm{~N} \mathrm{NH} \mathrm{NH}_{4} \mathrm{OH}$. Triplicate samples were analyzed as above (El-Morsy 2004).

\section{Time of contact}

To determine the optimal incubation time, a fixed adsorbent concentration of $200 \mathrm{mg} / \mathrm{l}$ of fungal biomass was added to $50 \mathrm{ml}$ of heavy metal solution containing an initial metal concentration of $200 \mathrm{mg} / \mathrm{l}$ of $\mathrm{Zn}, \mathrm{Cu}$ and $\mathrm{Pb}$. Three samples were taken at 5, 10, 15, 25, 35, 60, 120 and 1440 minutes at room temperature (El-Morsy 2004).

\section{Alkali-treatment of the biosorbent}

To generate ionic sites without significant modification of the cell wall structure before sorption, the mycelium was treated with $0.1 \mathrm{M} \mathrm{NaOH}$ at $120^{\circ} \mathrm{C}$ for $6 \mathrm{~h}$ and filtered through 0.45 $\mathrm{m} \mu$ millipore filter paper. The treated mycelium then was washed several times to reach neutral $\mathrm{pH}$ and oven dried at $60^{\circ} \mathrm{C}$. After that, Aliquots of 10, 50, 70, 100, 150, 200, 300, 400 and $600 \mathrm{ppm}$ were added to $250 \mathrm{ml}$ Erlenmeyer flasks with a fixed biomass of the alkali-treated biosorbent (200 $\mathrm{mg} / \mathrm{l})$. The flasks then were agitated on a rotatory shaker $(180 \mathrm{rpm})$ for 15 minutes at room temperature. The $\mathrm{pH}$ was adjusted to 4 in the case of $\mathrm{Pb}$ and 5 in the case of $\mathrm{Zn}$ and $\mathrm{Cu}$ (El-Morsy 2004).

\section{Metal biosorption by alkali treated-immobilized fungal biomass}

To each well of a percolating plate, $200 \mathrm{mg}$ of alkali-treated biosorbent was added, followed by a drop of $4 \%$ sodium alginate of high viscosity. A drop of $0.25 \mathrm{M} \mathrm{CaCl}_{2}$ was added to each well separately to form beads. The beads were collected and air dried to yield pellets. Dried pellets, each containing $200 \mathrm{mg}$ biosorbent biomass were added to conical flasks containing aliquots (50ml) of 10, 50, 70, 100, 150, 200, 300, 400 and $600 \mathrm{mg} / \mathrm{l}$ concentrations of zinc sulfate, copper sulfate and lead acetate. A constant $\mathrm{pH}$ of 4 in the case of $\mathrm{Pb}$ and 5 in the case of $\mathrm{Zn}$ and $\mathrm{Cu}$ and a time of contact of 15 minutes were used for all metal ions at room temperature. After measuring the residual metal concentration $\left(\mathrm{C}_{f}\right)$ in the solution, the beads were collected and regenerated using diluted acid $(0.1 \mathrm{M} \mathrm{HCl})$ followed by $3 \%$ bicarbonate. A control experiment was carried out using mycelium free alginate pellets.

\section{Biosorption of $\mathrm{Zn}, \mathrm{Cu}$ and $\mathrm{Pb}$ from polluted water}

10 Samples were collected from canals located near the industrial area of New Damietta in July 2012. The Samples contained metal ions at different concentrations. Immobilized fungal biomass (three pellets) was added to $250 \mathrm{ml}$ Erlenmeyer flasks containing $100 \mathrm{ml}$ of polluted water sample without adjustment of $\mathrm{pH}$. In a second experiment, the test was carried out at $\mathrm{pH} 4$ and $\mathrm{pH}$ 5. The flasks then were agitated on a rotatory shaker $(180 \mathrm{rpm})$ for 15 minutes at room temperature. The residual metal ion concentration was determined by A Perkin-2380 atomic absorption spectrophotometry.

\section{Biosorption mechanism}

To determine the quantity of metal that can be attracted and retained in an immobilized form, it is customary to express metal uptake (q) by the biosorbent as the amount of metal adsorbed per unit of biomass. The calculation of the metal uptake ( $\mathrm{mg} / \mathrm{g}$ dry biosorbent) is based on the material balance of the sorption system. The amount of metal adsorbed by the biosorbent from solution can be estimated from this formula: $q=V\left(C_{i}-C_{f}\right) / M($ Holan and Volesky, 1994) where $q$ is the metal ion uptake $(\mathrm{mg} / \mathrm{g}), \mathrm{C}_{\mathrm{i}}$ is the initial metal ion concentration (ppm), $\mathrm{C}_{\mathrm{f}}$ is the measured final concentration of the metal ion in the solution (ppm), $\mathrm{V}$ is the liquid sample volume (ml) and $\mathrm{M}$ is the starting biosorbent weight (mg). 
The sorption-isotherm relationship can be expressed mathematically by plotting $q$ versus $\mathrm{C}_{\mathrm{f}}$. This first was done in the classical work of Langmuir (1918) who studied activated carbon adsorption. The linear form of the Langmuir isotherm equation is represented by this equation: $\mathrm{q}=\mathrm{Q}_{\max } \mathrm{bC}_{\mathrm{f}} / 1+\mathrm{bC}_{\mathrm{f}}$.

Where Qmax is the maximum amount of metal per gram of biomass corresponding to saturation of the adsorption sites. The dissociation constant (b) is a coefficient related to the affinity between metals and biomass.

\section{Results}

\section{Occurrence of fungi in the polluted water}

Fourty-five fungal species were isolated from polluted water at Damietta's canals and drainages located near the industrial area of New Damietta (Table. 1). The majority of species were mitosporic (37 species of hyphomycetes and three species of agonomycetes). Zygomycetes were represented by three species while yeast was represented by two species. The frequent species were Mucor racemosus (50\%) followed by Aspergillus flavus (48\%), A. niger (36\%), A. fumigatus (30\%), Trichoderma Koningii (30\%) and Rhizopus oryzae (29\%).

\section{Influence of biomass, $\mathrm{pH}$ and time of contact on metal uptake}

Metal uptake varied with biomass concentration, $\mathrm{pH}$ and time of contact. The level of ion uptake rose with increasing biomass till $200 \mathrm{mg}$ and then decreased with increasing biomass (Fig. 1. a). Uptake rose with increasing $\mathrm{pH}$ up to 4 in the case of $\mathrm{Pb}$ and 5 in the case of $\mathrm{Zn}$ and $\mathrm{Cu}$ (Fig. 1 . b). The maximum uptake of all metals was achieved after 15 minutes and decreased promptly (Fig. 1. c).

\section{Biosorption mechanism}

Sorption isotherms of $\mathrm{Zn}, \mathrm{Cu}$ and $\mathrm{Pb}$ by dead biomass of M. racemosus are shown in (Table. 2). Sorption isotherms represented the distribution of metal ions between aqueous and solid phases (biomass) when the concentration increases as long as binding sites are not saturated. These isotherms permit the calculation of the adsorption capacities and dissociation constants of metal ions. The maximum uptake of $\mathrm{Cu}(60.13 \mathrm{mg} / \mathrm{g}), \mathrm{Zn}(57.67 \mathrm{mg} / \mathrm{g})$ and $\mathrm{Pb}(21.97 \mathrm{mg} / \mathrm{g})$ occurred at a biomass of $200 \mathrm{mg} / \mathrm{l}$.

\section{Metal biosorption by immobilized fungal biomass}

Uptake of $\mathrm{Zn}, \mathrm{Cu}$ and $\mathrm{Pb}$ increased after treatment with $0.1 \mathrm{M} \mathrm{NaOH}$ at $120^{\circ} \mathrm{C}$ for $6 \mathrm{~h}$ at biomass of $200 \mathrm{mg} / \mathrm{l}$. Accordingly, $\mathrm{NaOH}$ pretreatment was employed in experiments designed to test the efficiency of alginate-immobilized biomass in enhancing metal uptake. Alginate beads have the capacity to be laden and remove metal ions from metal solutions and water samples polluted with heavy metals. The best rate of uptake of alginate beads (q) occurs at $100 \mathrm{ppm}$ for $\mathrm{Zn}$ and $\mathrm{Pb}$ and at $150 \mathrm{ppm}$ for $\mathrm{Cu}$. In all heavy metals under study biosorption increased till a definite heavy metal concentration after which rate of uptake began to decrease by alginate beads. Results revealed a marked increase in uptake of all tested metals by the alkali treated alginate-immobilized biomass over free biomass in enhancing metal uptake. The best rate of uptake by alkali treated alginateimmobilized M. racemosus for $\mathrm{Zn}$ occurred at $100 \mathrm{ppm}(111.58 \mathrm{mg} / \mathrm{g}), \mathrm{Cu}$ occurred at $150 \mathrm{ppm}$ (121.33 mg/g) and Pb occurred at 100 ppm (96.15 mg/g) (Fig. 2).

\section{Biosorption of $\mathrm{Zn}$, $\mathrm{Cu}$ and $\mathrm{Pb}$ from polluted water}

Alkali treated alginate-immobilized biomass showed strong ability for removal of metal ions from polluted samples in the order $\mathrm{Pb}>\mathrm{Cu}>\mathrm{Zn}$ at $\mathrm{pH} 4$ while at $\mathrm{pH} 5 \mathrm{Cu}>\mathrm{Zn}>\mathrm{Pb}$ (Table. 3). 

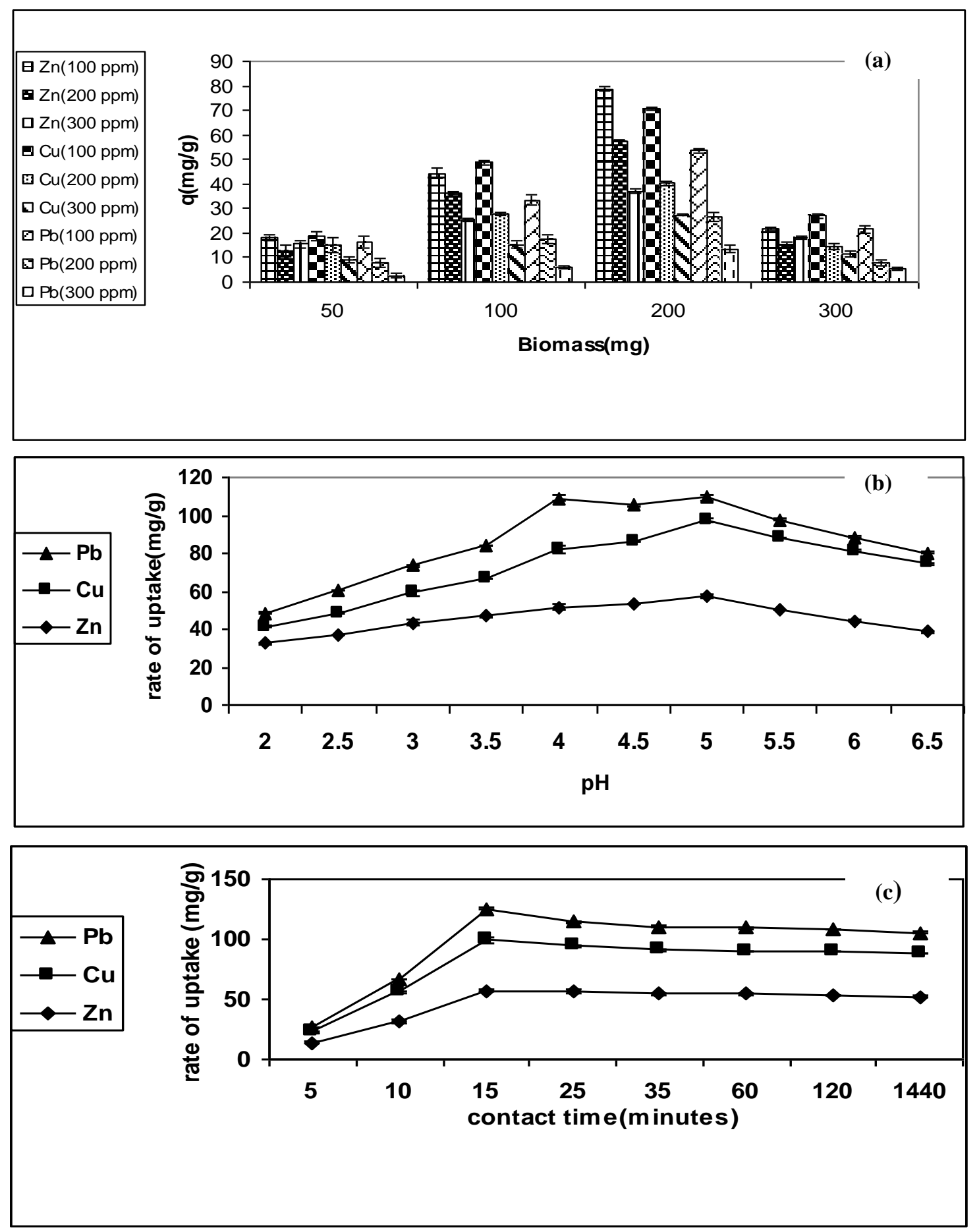

Fig.1 - Effect of biomass (a), pH (b), and contact time (c) by free biomass of M. racemosus. Each value is the average of three replicates.

\section{Discussion}

This study surveyed fungi from polluted water with the goal of identifying new species with metal-ion biosorbent potential. Fourty-five species were isolated. The most frequent species were Mucor racemosus, Aspergillus flavus, A. niger, A. fumigatus, Trichoderma koningii and Rhizopus oryzae. Mucor racemosus is the most frequent fungus in water samples which are polluted with heavy metals. This suggests that $M$. racemosus may be heavy metal-resistant fungus as a subject for the studies reported here. 
Table1 Fungi isolated from a polluted water of Damietta's canals and drainages located near the industrial area of New Damietta.

\begin{tabular}{|c|c|c|}
\hline \multicolumn{2}{|l|}{ Species } & \multirow{2}{*}{$\begin{array}{l}\text { \% of occurrence } \\
16\end{array}$} \\
\hline $\begin{array}{l}\text { Hyphomycetes :- } \\
\text { Aspergillus sulphureus }\end{array}$ & ( Fresenius ) Thom and Church & \\
\hline A. candidus & Link & 18 \\
\hline A. flavus & Link & 48 \\
\hline A. fumigatus & Fresenius & 30 \\
\hline A. niger & Van Tiegh & 36 \\
\hline A. terreus & Thom and Church & 13 \\
\hline A. clavatus & Desmazieres & 13 \\
\hline A. cervinus & Massee emend - Neill & 18 \\
\hline A. carneus & (Van Tiegh ) Bloohwitz & 15 \\
\hline A. terricola Var. Americana & (Marchal) & 12 \\
\hline A. wentii & (Wehmer) & 10 \\
\hline A. flavipes & (Brain.Et Sart.) Thom et Church & 14 \\
\hline Alternaria citri & Elliss et pieree apud. & 15 \\
\hline Acremonium guillemattii & (W.Gams) & 12 \\
\hline Ac. charticola & (Lindau) Gams & 13 \\
\hline Ac. falciform & (Carrion) Gams & 15 \\
\hline Ac. strictum & Gams & 7 \\
\hline Ampulliferina fagi & M.B.Ellis Spec.nov & 9 \\
\hline Botryotrichum piluliferum & Sacc.et March & 8 \\
\hline Curvularia pallescens & Boedijin & 9 \\
\hline Fusarium moniliforme & Sheldon & 11 \\
\hline F. oxysporium & Sehlecht & 14 \\
\hline Phialophora richardisae & Nannf & 9 \\
\hline Phialophora. cyclaminis & Beyma & 7 \\
\hline Penicillium corylophilum & Dierckx & 17 \\
\hline P. chermesinum & Biourge & 17 \\
\hline p. piscarium & Westling & 16 \\
\hline p. camembetri & Thom & 15 \\
\hline p. purpurogenum & Stoll & 16 \\
\hline p. citrinum & Thom & 17 \\
\hline p. notatum & Westling & 15 \\
\hline p. simplicissimum & (Oud.)Thom & 16 \\
\hline p. candidum & Link & 17 \\
\hline p. brevi compactum & Dierckx & 19 \\
\hline p. janthinellum & Biourge & 18 \\
\hline Trichoderma koningii & Oud & 30 \\
\hline Trichoderma piluliferum & Webster and Rifai & 27 \\
\hline Agonomycetes:- & & \\
\hline Demateaceous sterile mycelium & brown & 11 \\
\hline D. sterile mycelium & black & 12 \\
\hline Hyaline sterile mycelium & & 11 \\
\hline Zygomycota:- & & \\
\hline Mucor racemosus & Fresenius & 50 \\
\hline Rhizopus oryzae & Went et Prinsen & 29 \\
\hline Syncephalastrum racemosus & Scholer & 12 \\
\hline $\begin{array}{l}\text { Yeast:- } \\
\text { Geotrichum candidum }\end{array}$ & Link:Fr & 12 \\
\hline Trichosporon cutaneum & (De.Beurmann) Ota. & 14 \\
\hline
\end{tabular}

The isolated species were classified as very frequent $(>20 \%)$, frequent $(10-20 \%)$, or infrequent $(<10 \%)$ as adapted from (Tan and Leong 1989). 

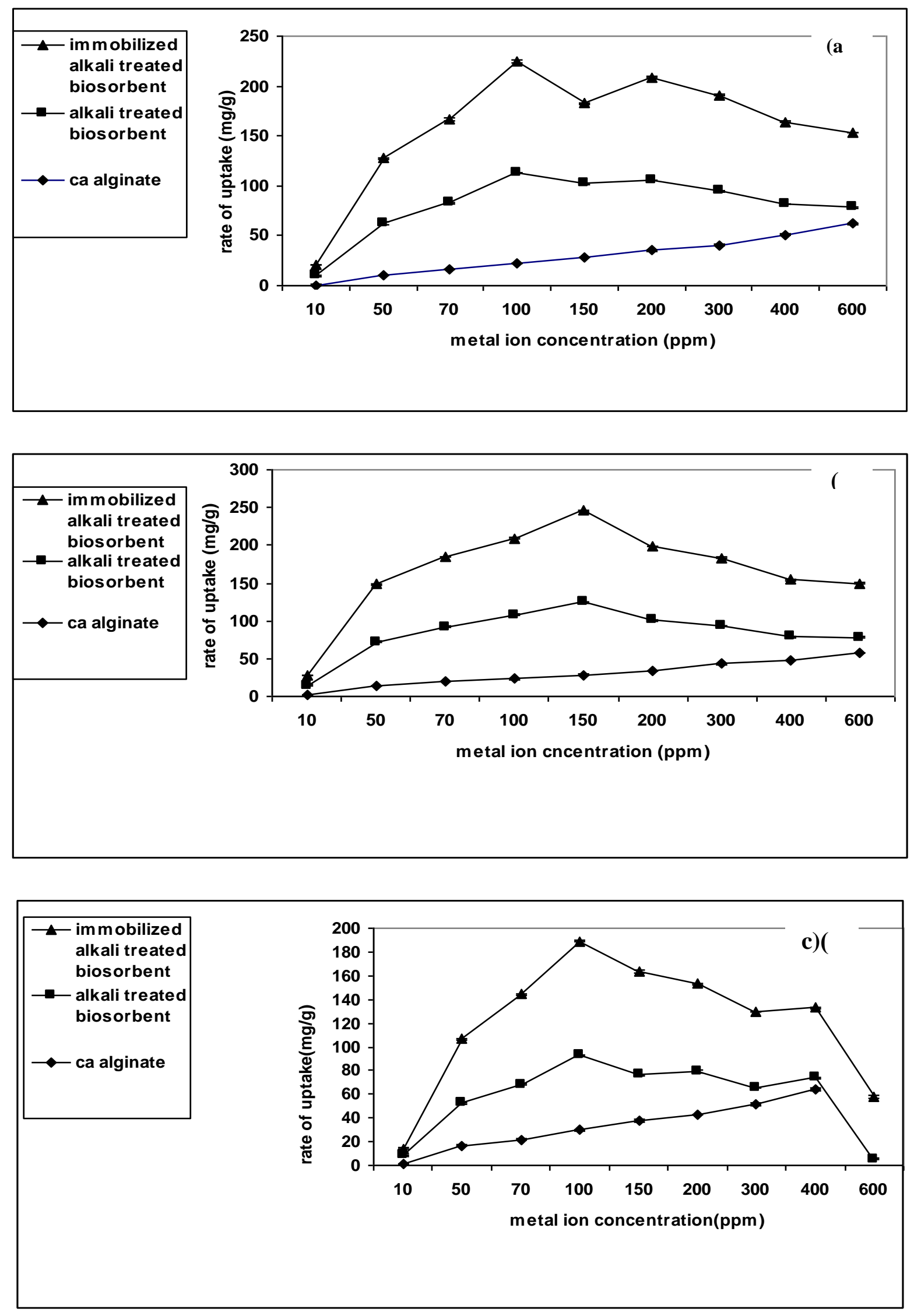

Fig. 2 - Biosorption capability of ca alginate, alkali treated and alkali treated alginate-immobilized Mucor racemosus for (a) $\mathrm{Zn}$, (b) $\mathrm{Cu}$ and (c) $\mathrm{Pb}$. 
Table 2 Uptake Capacities of various heavy metals by Mucor racemosus derived from the Langmuir equation $\left(\mathrm{q}=\mathrm{Q}_{\max } \mathrm{bC}_{\mathrm{f}} / 1+\mathrm{b} \mathrm{C}_{\mathrm{f}}\right.$. $)$

\begin{tabular}{llll}
\hline Parameters/metal & $\mathbf{Z n}$ & $\mathbf{C u}$ & $\mathbf{P b}$ \\
\hline A.W.(g) & 65.39 & 63 & 207.19 \\
Q (mg/g) & 57.67 & 60.13 & 21.97 \\
Q(mmole/g) & 0.88 & 0.95 & 0.11 \\
b(mM) & 0.3 & 0.46 & 2.05 \\
Affinity $(1 / \mathrm{b})$ & 3.3 & 2.17 & 0.49 \\
\hline
\end{tabular}

$\mathrm{Q}=$ maximum absorption capacity, $\quad \mathrm{b}=$ dissociation constant, $\mathrm{A} \cdot \mathrm{W}=$ Atomic Weight

\section{Biosorption by free biosorbent and effect of biomass concentration}

Fourest \& Roux 1992 reported that metal-ion uptake per gram of biosorbent increases as long as the biosorbent is not saturated. However, uptake values also depend on the nature and the origin of the biosorbent itself (Luef et al. 1991). In the present study, uptake of $\mathrm{Zn}, \mathrm{Cu}$ and $\mathrm{Pb}$ by free biosorbent in solution varied depending on the initial metal concentration, biomass concentration, time of contact and $\mathrm{pH}$. With $M$. racemosus, the optimal time for biosorption was 15 minutes after contact. This result is similar to that obtained by Volesky \& Philips 1995 (Saccharomyces cerevisiae), El-Morsy 2004 (Cunninghamella echinulata), who reported that most metal biosorption was achieved in 5-15 minutes, followed by residual and slower additional metal deposition (Tsezos \& Volesky 1981), conceivably indicating a secondary metal binding mechanism. Alike, the maximum uptake by M. racemosus occurred at $\mathrm{pH} 4$ for $\mathrm{Pb}$ and at $\mathrm{pH} 5$ for $\mathrm{Cu}$ and $\mathrm{Zn}$ with uptake falling with rising $\mathrm{pH}$. The effects of $\mathrm{pH}$ on the biosrbent capabilities of fungal biomass appeared to vary with assay conditions, the particular metal ion and fungal species. Analogous to results reported here, $\mathrm{pH}$ between 4 and 5 was reported as optimal for biosorption of $\mathrm{Zn}$ and $\mathrm{Cu}$ by Saccharomyces cerevisiae (Tsezos \& Volesky 1981, Tobin et al. 1984, Volesky \& Philips 1995) found that $\mathrm{pH}$ near 4 was optimal for metal uptake by Rhizopus arrhizus. In contrast, Luef et al. 1991 reported that biosorption of $\mathrm{Zn}$ by mycelium of A. niger, Penicillium chrysogenum and Clavicipis paspali rose with increasing $\mathrm{pH}$ up to 9. Fourest and Roux 1992 reported that the optimal uptake of $\mathrm{Zn}$ and $\mathrm{Pb}$ by Rhizopus arrhizus was achieved at a neutral $\mathrm{pH}$ and $\mathrm{pH}$, respectively. Lewis \& Kiff 1988 found that acidic $\mathrm{pH}$ reduced metal biosorption by the latter, a reduction that could be attributed to the precipitation of metal ions.

\section{Biosorption mechanism}

The sorption process involves biomass as a solid phase and a liquid phase containing metal ions, with ion distribution between solid and liquid phases determined by the affinity of biomass for metals. The quality of the biosorbents material is evaluated in terms of how much metal it can attract and retain in an immobilized form. It is customary to determine metal uptake (q) by the biosorbents as the amount of metals bound by the unit of biomass. Sorption isotherm followed the typical Langmuir adsorption pattern (Ruthven 1984). The results presented here for M. racemosus are consistent with the Langmuir - isotherm model (Fourest \& Roux 1992).

Alkali treatment of biosorbents pretreatment of the biomass was performed following the work of (Kapoor \& Viraraghavan 1997, 1998 a \& b, Kapoor et al. 1999). Alkali treatment improved the capacity of the $M$. racemosus biosorbents to chelate metal ions, especially the higher biomass of $200 \mathrm{mg} / \mathrm{l}$. The higher affinity might be attributed to the chitin and chitosan content of the fungus cell wall, exposed after $\mathrm{NaOH}$ treatment. $\mathrm{NaOH}$ appears to remove amorphous polysaccharides from the cell wall, generating accessible space within the $\beta$-glucan-chitin skeleton and hence permitting metal ions to precipitate on this surface (Tsezos \& Volesky 1981, Fourest \& Roux 1992). Similaraly formaline pretreatment significantly improved the surface active site that actually participitates in Cu biosorption (Kapoor \& Viraraghavan 1997, 1998 a \& b, Kapoor et al. 1999). 
Table 3 Biosorption efficiency $(\%)$ of $\mathrm{Zn}, \mathrm{Cu}$ and $\mathrm{Pb}$ from polluted water by alginate pellets of alkali treated-immobilized Mucor racemosus.

\begin{tabular}{lrll}
\hline \multicolumn{1}{l}{ Parameters/metal } & Zn & Cu & Pb \\
\hline $\mathrm{pH}=4$ & 80.55 & 81.11 & 96.15 \\
$\mathrm{pH}=5$ & 95.04 & 95.88 & 83.25 \\
$\begin{array}{l}\text { Control (without } \\
\text { adjustment) }\end{array}$ & $\mathrm{pH}_{56.65}$ & 63.10 & 39.37 \\
\hline
\end{tabular}

Kapoor et al. 1999 reported that both Langmuir and Freundlich isotherm data at $\mathrm{pH} 5$ at $\mathrm{Cu}$ biosorption by $\mathrm{NaOH}$ pretreated Aspergillus niger biomass were statistically significant at $95 \%$ confidence level. The alkaline treatments including sodium hydroxide, potassium hydroxide, alkaline detergents or other alkaline reagents ruptures the cell walls of microbes and exposes additional functional groups for metal ion binding. The residual alkalinity may result in the hydrolysis of certain metals, thus enhancing the biosorption capacity of the biomass (Brierley 1990). The biomass of Aspergillus niger pretreated with $\mathrm{Na}_{2} \mathrm{CO}_{3}(0.2 \mathrm{~N})$ exhibited the maximum biosorption capacity $(20.82 \mathrm{mg} / \mathrm{g})$ for $\mathrm{Cu}$.

Treatment of $A$. niger with $\mathrm{NaOH}(0.2 \mathrm{~N}$ and $0.5 \mathrm{~N})$ yield equivalent adsorption capacity $(18.81 \mathrm{mg} / \mathrm{g})$ the biosorption capacity of $(16.5 \mathrm{mg} / \mathrm{g})$ recorded for fungal biomass pretreated with $\mathrm{NaHCO}_{3}(0.2 \mathrm{~N})$ and detergent was observed to reduce up to $22 \%$ in comparison to maximum recorded potential of $>37 \%$ in alkali pretreatment (Javaid et al. 2011).

Baik et al. 2002 reported that Aspergillus sp. has the ability to absorb maximum level of $\mathrm{Cu}$ when treating the cell fraction with $\mathrm{NaOH}$. Volesky \& Philips 1995 explained this is due to microbial biomass consisting of poor mechanical strength and little rigidity. However, biosorbents are hard enough to withstand and the application of pressures, water retention capacity, porous and transport to metal ion sorbate species.

Physical and chemical treatments used to enhance the metal uptake capacity of the biomass, which led to removal, hiding or exposing chemical groups that binding or exchange with the adsorbed metal ions (Saleh et al. 2009). Similar enhancement in metal uptake capacity of the fungal biomass regarding alkali pretreatment was recorded by (Yan \&Viraraghavan 2000, El-Morsy 2004, Das et al. 2007). It could be due to chemical modifications of the cell wall components. The modification of biomass probably destroys autolytic enzymes that cause purification of biomass and remove lipids and proteins that mask the reactive sites (Muraleedharan \&Venkobachar 1990).

\section{Immobilization of the biosorbents}

Immobilization has been reported to enhance the capacity of fungal biomass for chelating metal ions (Lewis \& Kiff 1988, Yousef 1997). Here, alginate immobilization of alkali treated biosorbents beads resulted in a nearly two fold increase in metal-ion uptake over free biosorbents. Alginate carboxyl groups are known to play an important role in metal binding (Kuyucak \& Volesky 1989). Previous studies have revealed a high capacity of alginate-biomass beads to remove metal ions from polluted water (El-Morsy 2004).

In this study, up to $96.15 \%, 81.11 \%$ and $80.55 \%$ of $\mathrm{Pb}, \mathrm{Cu}$ and $\mathrm{Zn}$ were removed at $\mathrm{pH} 4$ respectively. While at $\mathrm{pH} 5$ up to $95.88 \%, 95.04 \%$ and $83.24 \%$ of $\mathrm{Cu}, \mathrm{Zn}$ and $\mathrm{Pb}$ were removed respectively. Kapoor \& Viraraghavan 1998b used A. niger biomass immobilized in polysulfone polymer in the form of spherical beads to remove $\mathrm{Zn}, \mathrm{Cu}$ and $\mathrm{Pb}$ ions from industrial waste water. A packed bead column containing $A$. niger beads removed $58 \% \mathrm{~Pb}, 38 \% \mathrm{Cu}$ and $16 \% \mathrm{Zn}$ from the culture in $12 \mathrm{~h}$. Biomass immobilized on polyacrylamide similarly was non immobilized biomass for metal biosorption (Yousef 1997). The uptake of the heavy metals ( $\mathrm{Cu}, \mathrm{Co}$ and $\mathrm{Fe}$ ) was examined in the immobilized column experiments (Rhizopus delemar immobilized on polyurethane foam). More than $92 \%$ heavy metal removal from a mixed solution was achieved during the 5 cycles (Kolishka Tsekova \& Galin Petrov 2002). More recently, biosorption of metals by 
immobilized cell system has been used efficiently for removal of metals from industrial effluent (Gadd \&White 1993, Gulay et al. 2003, Yakup et al. 2004, Sun et al. 2010, Hemambika et al. 2011, Tan \& Ting. 2012, Ahemad \& Kibret 2013). Cells with such abilities are immobilized either as entrapped biomass or as a biofilm to form a system for treating waste water known as a bioreactor (Qureslii et al. 2001). Immobilized cells of Kluyveromyces marxianus allowed for high removal capacity for $\mathrm{Cu}$, $\mathrm{Co}$ and $\mathrm{Zn}$ where 1.6, 1.5 and 1.3 fold increase were recorded compared to free cells (Yousef 1997).

The biosorption of immobilized cells of Aspergillus sp. was $60.94 \%$ of $\mathrm{Cu}$, Penicillium sp. was $97.21 \%$ of $\mathrm{Cd}$ and Cephalosporium sp. was $73.27 \%$ of $\mathrm{Pb}$; whereas the dead cells of Aspergillus sp. was $46.91 \%$ of $\mathrm{Cu}$, Penicillium sp. was $95.27 \%$ of $\mathrm{Cd}$ and Cephalosporium sp. was $70.67 \%$ of $\mathrm{Pb}$. All these results reveal that the adsorption capacities of the immobilized fungal cells were greater than that of dead cells (Hemambika et al. 2011). Johncy Rani et al. 2010 found similar adsorption capacity of $\mathrm{Cu}, \mathrm{Cd}$ and $\mathrm{Pb}$ in the immobilized cells of Bacillus sp., pseudomonas sp. and Micrococcus sp. respectively. Leusch et al. 1995 explained this is because dead fungal cells consist of small particles with low density, poor mechanical strength and little rigidity. Hence, the immobilization of biomass is necessary on before subjecting to biosorption. Holan \& Volesky 1994 explained that immobilized cells offers many advantages including better reusability, high biomass loading and minimum clogging in continuous flow systems. Adsorption of heavy metals was also dependent on cell density in calcium alginate beads. The results obtained for the uptake of heavy metals under study show us that the metal accumulation by Mucor racemosus is a chemical, equilibrated and saturable mechanism. Thus, adsorption increases when the initial metal concentration rises as long as the binding sites are not saturated.

Zygomycetes sp such as Mucor sp, Rhizopus arrhizus and Absidia orchidis generally are reported to be efficient biosorbent agents (Lewis \& Kiff 1988, Fourest \& Roux 1992, Mueler et al. 1992, Holan \& Volesky 1995). The work reported here demonstrates M. racemosus to be as effective as Cunninghamella echinulata and Rhizopus sp. This based on the finding that immobilized biomass of $C$. echinulata was able to remove ions from a natural environment up to 95 $\%$ (El-Morsy 2004). It was also found that maximum copper removal by Rhizopus arrhizus of $98 \%$ was obtained using the biosorption kinetics of copper under optimum conditions. (Preetha \& Viruthagiri 2007).

\section{Conclusion}

Biomass of $M$. racemosus efficiently is able to remove $\mathrm{Zn}, \mathrm{Cu}$ and $\mathrm{Pb}$ from a solution. This capacity was enhanced when the biomass was alkali treated and immobilized. The fungus in its immobilized form also was able to remove ions from a natural environment up to $96 \%$, therefore the fungus is proposed as an effective biosorbent for removal of heavy metals in waste water treatment.

\section{References}

Ahemad M, Kibret M. 2013 - Recent Trends in Microbial Biosorption of Heavy Metals: A Review Biochemistry \& Molecular Biology, 1(1),19-26.

Apel ML, Torma AE. 1993 - The Minerals, Metals and Materials Society. USA Biohydrometalargy Technology 2, 25-33.

Artola A, Balaguer DM, Rigola M. 1997 - Heavy metal binding to anaerobic sludge. Water Research 31, 997-1004.

Awofolu OR, Okonkwo OJ, Merwe RVD. 2006 - A new approach to chemical modification protocols of Aspergillus niger and sorption of lead ion by fungal species. Electronic Journal of Biotechnology 9, 341-348.

Baik WY, Bae JH, Cho KM, Hartmeier W. 2002 - Biosorption of heavy metals using whole mold mycelia and parts thereof. Bioresour. Technol. 81, 167-170. 
Brierley CL. 1990 - Metal immobilization using bacteria. Microbial Mineral Recovery. Eds. McGraw-Hill Publishing, New York p, 303-323

Cooke WB. 1963 - A Laboratory Guide to Fungi in Polluted Waters, Sewage and Sewage Treatment Systems: Their Identification and Culture. Cincinnati, Ohio: U.S. Department of Health, Education and Welfare p, 132.

Das N, Charumathi D, Vimala R. 2007 - Effect of pretreatment on $\mathrm{Cd}^{2+}$ biosorption by mycelial biomass of Pleurotus florida. African Journal of Biotechnology 6, 2555-2558.

El-Morsy EM. 2004 - Cunninghamella echinulata a new biosorbent of metal ions from polluted water in Egypt. Mycologia 96, 1183-1189.

Fourest E, Roux JC. 1992 - Heavy metal biosorption by fungal mycelial by products: mechanisms and influence of pH. Appl. Microbial. Biotechnol 3, 399-403.

Gadd GM. 1986 - Fungal responses towards heavy metals. In: Herbert RA, Gadd GM. eds. Microbes in Extreme Environments. London: Academic Press p, 83-110.

Gadd GM, White CM. 1989 - Removal of thorium from simulated acid process streams by fungal biomass. Biotech. Bioeng. 33, 592-597.

Gadd GM, White CM. 1993 - Microbial treatment of metal pollution - a working biotechnology.

Gulay B, Sema B, Yakup AM. 2003 - Biosorption of heavy metal ions on immobilized white-rot fungus Trametes versicolor. J. Hazard. Mater. 101, 285-300.

Hemambika B, Johncy Rani M, Rajesh Kannan V. 2011 - Biosorption of heavy metals by immobilized and dead fungal cells: A comparative assessment. Journal of Ecology and the Natural Environment Vol. 3(5), 168-175.

Holan ZR, Volesky B. 1994 - Biosorption of Pb and Ni by biomass of marine algae. Biotechnol. Bioeng. 43, 1001-1009.

Holan ZR, Volesky B. 1995 - Accumulation of cadmium, lead and nickel by fungal and wood biosorbents. Applied. Bioch. Biotech. 53, 133-146.

Huang CP. 1996 - Application of Aspergillus oryzae and Rhizopus oryzae. Water Research 30, 1985-1990.

Javaid A, Bajwa R, Manzoor T. 2011 - Biosorption of heavy metals by pretreated biomass of Aspergillus niger. Pak. J. Bot 43, 419-425.

Johncy Rani M, Hemambika B, Hemapriya J, Rajesh KV. 2010 - Comparative assessment of heavy metal removal by immobilized and dead bacterial cells. A biosorption approach. Afr. J. Environ. Sci. Technol. 4, 77-83.

Kapoor A, Viraraghavan T, Cullimore D. 1999 - Removal of heavy metals using the fungus Aspergillus niger. Bioresource. Technology. 70, 95-104.

Kapoor A, Viraraghavan T. 1997. Heavy metal biosorption sites in Aspergillus niger. Biores. Technol. 61, 221-227.

Kapoor A, Viraraghavan T. 1998a - Application of immobilized Aspergillus niger biomass in the removal of heavy metals from an industrial wastewater. J Environ Sci Health. Pt. A. Toxic Hazard-Subst Environ Eng Vol. A 33, 7, 1507- 1514.

Kapoor A, Viraraghavan T. 1998b - Biosorption of heavy metals on Aspergillus niger, effect of pretreatment. Biores. Technol. 63, 109-113.

Kolishka Tsekova A, Galin Petrov B. 2002 - Removal of Heavy Metals from Aqueous Solution Using Rhizopus delemar Mycelia in Free and Polyurethane - Bound Form. Natur. for. sc. 57, 629-633.

Kuyucak N, Volesky B. 1989c - The mechanism of cobalt biosorption. Biotech. Bioeng. 33, 823831.

Langmuir I. 1918 - The adsorption of gases on plane surfaces of glass, mica and platinum. J. Am. Chem.Soc 40, 1361-1403.

Leusch A, Holan ZR, Volesky BJ. 1995 - Biosorption of heavy metals in water supplies production of oil industry. J. Chem. Technol. Biotechnol. 62, 279-288.

Lewis D, Kiff RG. 1988 - The removal of heavy metals from aqueous effluents by immobilized fungal biomass. Environmental Technology Letters 9, 991-998. 
Loukidou MX, Matis KA, Zouboulis AI. 2003 - Removal of $\mathrm{As}^{2+}$ from waste waters by chemically modified fungal biomass. Water Research 37, 4544-4552.

Luef E, Prey T, Hubicek CP. 1991 - Biosorption of zinc by fungal mycelial wastes. Appl. Microbial. Biotechnol. 34, 688-692.

Mueler MD, Wolf DC, Beveridge TJ, Bailey GW. 1992 - Sorption of heavy metals by the soil fungi Aspergillus niger and Mucor rouxii. Soil Biol. Biochem. 24, 129-135.

Muraleedharan TR, Venkobachar C. 1990 - Mechanism of biosorption of copper (II) by Ganoderma lucidium, Biotechnol. Bioeng. 35, 320-325.

Nitin W. Ingole, Sachin V. Dharpal. 2012 - State of art of biosorption technique for treatment of heavy metals bearing wastes. IJAET/Vol.III/ Issue II/April-June, 143-153.

Nur Liyana, I, Nur Ain Izzati MZ, Tan SG. 2011 - Tolerance and biosorption of copper $(\mathrm{Cu})$ and lead $(\mathrm{Pb})$ by filamentous fungi isolated from a freshwater ecosystem. Journal of Environmental Science, 23, 824-830.

Park JM, Park D, Yun YS, Jo JH. 2005 - Mechanism of hexavalent chromium removal by dead fungal biomass of Aspergillus niger. Water Research 39, 533-540.

Preetha B., Viruthagiri T. 2007 - Application of response surface methodology for the biosorption of copper using Rhizopus arrhizus. Journal of Hazardous Materials 143, 506-510.

Qureslii FM, Badar U, Ahmed N. 2001 - Biosorption of copper by a bacterial biofilm on a flexible poly vinyl chloride conduit .Appl. Environ. Microbiol. 67, 4349-4352.

Ruthven DM. 1984 - Principles of Adsorption and Adsorption Processes. New York. Wiley. p, 464.

Saleh M, Al-Garni M, Khaled G, Abdulaziz SB. 2009 - Biosorption characteristics of Aspergillus fumigatus in removal of cadmium from an aqueous solution. African Journal of Biotechnology 8, 4163-4172.

Siddiquee S, Aishah S, Azad S, Shafawati S, Naher L. 2013 - Tolerance and biosorption capacity of $\mathrm{Zn}^{2+}, \mathrm{Pb}^{2+}, \mathrm{Ni}^{3+}$ and $\mathrm{Cu}^{2+}$ by filamentous fungi (Trichoderma harzianum, T. aureoviride and T. virens). Advances in Bioscience and Biotechnology 4, 570-583.

Sun YM, Horng CY, Chnag FL, \& Tiang WX. 2010- Biosorption of lead, Mercury and Cadmium by

Aspergillus terreus immobilized in natural matrix. Polish Journal of Microbiology 59, 37-44.

Tan TK, Leong WF. 1989 - Succession of fungi on wood of Avicennia alba and A. lanata in Singapore. Can. J. Bot. 67, 2686-2691.

Tan WS, Ting AS. 2012 - Efficacy and reusability of alginate-immobilized live and heatinactivated Trichoderma asperellum cells for $\mathrm{Cu}$ (II) removal from aqueous solution. Bioresour Technol. 2012 No6v; 123: 290-5.

Taylor JE, Hyde KD, Jones EBG. 1999 - Endophytic fungi associated with the temperate palm Trachcarpus fotunei within and outside its natural geographic range. New Phytologist 142,335-346.

Tobin JM, Copper DG, Neufeld RJ, 1984 - Uptake of metal ions by Rhizopus arrhizus. Appl. Environ. Microbiol. 47, 821-824.

Tsezos M, Volesky B. 1981 - Biosorption of uranium and thorium. Biotech. Bioen. 23, 583-604.

Venkateswerlu G, Stotzky G. 1989 - Binding of metals by the cell walls of Cunninghamella blakesleeana growing in the presence of copper or cobalt. Appl. Microbiol. Biotech. 31, 619-625.

Volesky B, Holan ZR. 1995 - Biosorption of heavy metals. Biotechnol. Prog. 11, 235-250.

Volesky B, Phillips HA. 1995 - Biosorption of heavy metals by Saccharomyces cerevisiae. Appl. Microbiol. Biotechnol. 42, 797-806.

Yan G, Viraraghavan T. 2000 - Effect of pretreatment on the bioadsorption of heavy metals on Mucor rouxii. Water SA 26, 119-123.

Yakup AM, Gulay B, Meltem Y, Sema B, Omer G. 2004 - Biosorption of Hg2+,Cd2+ and Zn2+ by Ca-alginate and immobilized wood-rotting fungus Funalia trogii, J. Hazard. Mater. B. 109, 191-199. 
Yazdani M, Chee KY, Faridah A, Tan SG. 2010 - An in vitro study on the adsorption, absorption and uptake capacity of $\mathrm{Zn}$ by the bioremediator Trichoderma atroviride. Environmental Asia, 3, 53-59.

Yousef HH. 1997 - Bioaccumulation of metal cations by free and immobilized cells of Kluveromyces marxianus. Adv. Food. Sci. 19,120-123. 